\title{
Fishermen community empowerment strategy through rural fisheries business development Program (Pump) by marine and fisheries office of Padang
}

\author{
Riki Fernando ${ }^{1}$, Asnil ${ }^{2}$, Erianjoni ${ }^{3}$ \\ ${ }^{123}$ Uninversitas Negeri Padang, Padang - Indonesia, (fernandoriki_92@yahoo.co.id)
}

\begin{abstract}
This study was based on the low economic condition of small-scale fishermen community in Padang. Ministry of Marine Affairs and Fisheries launched an empowerment of fishermen community through Rural Fisheries Business Development program (PUMP) implemented by the Marine and Fisheries Office of Padang City. The purpose of this research was to see the results of the empowerment strategy toward fishermen community in Padang through Rural Fisheries Business Development Program (PUMP). This research used qualitative by using descriptive method, informant determined by Purposive Sampling. The type of data consisted of primary and secondary data. Data were collected through observation, interview, and documentation study. Data collection tools included interview guides, observation guides, and field notes. Data validity test utilized source triangulation. Data analysis used SWOT analysis through data processing, data analysis, data reduction, and conclusion.
\end{abstract}

Keywords: Empowerment, Fisherman, Rural Fisheries Business Development Program (PUMP)

\section{Introduction}

The sea is a very valuable asset owned by every maritime country, because the sea stores an invaluable wealth. Indonesia as an archipelagic country, most of whose territory consists of the sea, has a huge and varied fishery potential. Its fisheries potential is an economic potential that can be utilized for the future of the nation, as well as the backbone of national development. Taking advantage of sea as marine resources requires participation from various parties such as government, and the public. The central and local government in accordance with the authority need to conduct the Marine Management for the greatest prosperity of the people through the utilization and exploitation of Marine Resources using new economic principles, while the people also participate in management of these resources in order to utilize the sea as a work plaace for fishermen.

Although we know the sea is very rich in natural products, but this does not guarantee the coastal communities who work as fishermen can prosper. In reality, the life of the fishermen community is always poverty-stricken, even the life of fishermen is often identified with poverty. Padang is one of the cities in Indonesia which is on the seafront, making the surrounding community dabbling with 
the sea to be called fishermen. Many people in the city who work as fishermen have not been able to meet their daily needs such as, food, and education. This is clearly inversely proportional to the rich potential of the sea around the city.

Ministry of Marine Affairs and Fisheries has launched many superior programs in to alleviate fishermen community poverty, which aims to improve the economy of fishermen community. One of the programs launched was the PUMP (Development of Rural Enterprises) regulated in Ministerial Regulation No. 41/2011 on implementation guidelines of national program of independent community empowerment of marine and fisheries. This program aims to (1) Improve fisherman's capability and income through developing small-scale fishing business activities in rural areas in accordance with the potential of fish resources; (2). Grow fishing entrepreneurship in rural areas, (3). Improve the fishery economic institutional function into a network or partner institution in access to capital.

Forms of assistance provided in the form of Public Awareness Fund (BLM) which is transferred through KUB chairman's accounts of each group, and then the group leaders buy the necessity to go to sea to support the livelihood of fishermen. The form of assistances needed are, in the form of fishing gear, Lontel machine, Yamaha 50PK Machine, Net, Viber, as well as fish house Peraharu. Not only in terms of assistance, the Department of Marine Affairs and Fisheries also provides socialization and counseling to the fishermen community for the creation of creative economy in the fishermen community and can take advantage of the assistance provided. In the provision of assitances, there are still many problems found, such as the inequality of distribution of aid, etc.

The main problem formulation proposed in this research is how community empowerment of Padang fishermen strategy through Rural Fisheries Business Development Program by Marine and Fishery Office of Padang.

\section{Method}

This research used qualitative approach with descriptive method to find out picture how fisherman community empowerment of Padang City strategy through Rural Fisheries Business Development Program by Marine and Fishery Office of Padang City. Using this approach, the author attempted to interact and build communication with the parties needed in this study. This research also interpreted or translated with the authory's own interpretation on the research's results obtained from correspondents in the field as an interviewer to obtain an explanation of the existing conditions.

The author used several data collection techniques, including interviews and documentation. Interview is a data collection technique used by the author to obtain verbal information through frequently asked questions and face to face with people who can give information to the author. So, the author can gather as much as relevant information as possible with a mix of interviews that have been prepared beforehand. Documentation is a technique of collecting data and studying documents and written materials and other materials related to the research problem on the object of research. In this case, the author used data analysis technique through SWOT analysis, identification of various factors systematically to formulate the expected strategy to solve the problem. This analysis was based on logic that can maximize strengths and opportunities but simultaneously minimize weaknesses and threats.

\section{Discussion}

According to Suharto (2010),empowerment is a process and a goal.As a process, empowerment is a series of activities to strengthen the power of weak groups in a community, including individuals experiencing poverty issues. 
From the above statement,the author could draw a conclusion that empowerment is a series of efforts or a program that makes the community more empowered and independent.It coincides with the program launched by the Ministry of Marine Affairs and Fisheries, in an effort to empower smallscale fishing communities.The program is called Rural Fisheries Business Development Program (PUMP).In addition, Sulistiani in Rinaldi (2010) says that the goal to be achieved from an empowerment is to shape individuals and society to be independent. The objective of the PUMP program itself is to increase the capability and income of fishermen through the development of small-scale fishing business activities in rural areas in accordance with the potential of fish resources, fostering fishermen entrepreneurship in rural areas, increasing the fishermen economic institutional function into networks or partners of financial institutions to gain wider access of capitalization.

This research tried to study about the strategy of fishermen community empowerment of Padang through Rural Fisheries Business Development Program (PUMP) by the Marine and Fishery Office of Padang.The method of writing this research incorporated SWOT analysis analysis technique. Saiful Sagala (2011) defines SWOT analysis as a one stage in strategic management involving an environmental analysis approach. The process of assessing strengths, weaknesses, opportunities and common barriers to the organization. Below are the weaknesses, strengths, opportunities and threats found in the field.

\section{Strengths in Fishermen Community Empowerment of Padang through Rural Fisheries Business Development Program by Marine and Fishery Office of Padang City}

Hunger \& Wheelen in Freddy Rangkuty (2015) says that, strengths are: resources, skills or other advantages, relative to competitors and market needs of served or wanted to be served by organizations. Strength is comparative to the organization/company in the market. In the implementation of fishermen community empowerment of Padang through Rural Fisheries Business DevelopmentProgram (PUMP) by Marine and Fishery Office of Padang;the strengths found in the field are: the grant of Rp100 million per KUB,implementation of sustainable revolving funds,socialization of the utilization of catch, obtaining new fishing facilities and infrastructure. KUB as a capital assistance facility for KUB members. Giving rewards to the best KUB, and punishment for irresponsible KUB. KUB recipients of PUMP program assistance must be a legal or incorporated entity. Creating an independent fisherman. Aid recipients are fishermen, and possessed fisherman's tools.

\section{Weaknesses in Fishermen Community Empowerment of Padang through Rural Fisheries Business Development Program by Marine and Fishery Office of Padang City}

Hunger \& Wheelen in Freddy Rangkuty (2015) say that: weaknesses are limitations or deficiencies in resources, skills and capabilities that seriously hamper the effective performance of a company/organization. In the implementation of the program, weaknesses found in the field as follow: struggling to build fisherman's character, revolving funds do not go according to the agreement, less socialization and evaluation from related government or field workers, low responsible members, lack of government oversight, weak human resources in developing KUB, lack of supervisor, lack of verification of fishermen or administration data.

\section{Opportunities in Fishermen Community Empowerment of Padang through Rural Fisheries Business Development Program by Marine and Fishery Office of Padang City}

According to Hunger \& Wheelen in Freddy Rangkuty (2015), opportunities are an important situation profitable for the company/organization. Important chances are one source of opportunity. Based on the experts' opinion above, a chance will be achieved by the program. As well as related to this research, the opportunities found in the implementation of Fishermen Community Empowerment of Padang through Rural Fisheries Business Development Program by Marine and Fishery Office of Padang City are as follows: KUB can open a fisherman cooperative, improved education of fishermen's children, opening business opportunities in addition to catching fish 
(fishing), low loan sharks' action, managing the catch by creating a creative economy, abundant natural resources, the best KUB will prioritize ongoing assistance.

Threats in Fishermen Community Empowerment of Padang through Rural Fisheries Business Development Program by Marine and Fishery Office of Padang City

According to Hunger \& Wheelen in Freddy Rangkuty (2015), threats are the main disruption to the present or desirable position of a company/organization. From the definition above, threats are all things that hinder a program. According to Hunger \& Wheelen in Freddy Rangkuty (2015), threats are the main disruption to the present or desirable position of a company/organization. From the definition above, threats are all things that hinder a program.

\section{Strategies in Fishermen Community Empowerment of Padang through Rural Fisheries Business Development Program by Marine and Fishery Office of Padang City}

SWOT identification (Strengths, Weaknesses, Opportunities and Threats) is the first step in formulating the fisherman community empowerment through Rural Fisheries Business Development program (PUMP) by Marine and Fishery of Padang City, based on the identification of internal and external factors, namely strengths, weaknesses, opportunities and threats. Below are the details:

Tabel 1. SWOT analysis of fisherman community empowerment in Padang through PUMP program

Strengths (S) Weaknesses (W)

1. Rp.100 million grants per KUB.

2. Implementation of sustainable revolving funds

3. Socialization of the utilization of catch.

4. Obtaining new catching facilities and infrastructure.

5. KUB as a capital assistance facility for KUB members.

6. Rewards for the best KUB, and punishment for irresponsible KUB

7. KUB recipients of the PUMP program must be a legal or incorporated entity.

8. Creating independent fishermen.

9. Assistance recipients are fishermen, and possess necessary tools

Opportunities (O)

1. KUB can open a fishing cooperative.

2. Improved education of fishermen's children.

3. Opening business opportunities in addition to fishing.

4. Lower loans from loan sharks.

5. Managing the catch by creating a creative economy.

6. Abundant natural resources.

7. The best KUB will be prioritized for sustained assistance.
1. Struggling to improve fishermen's character.

2. Revolving funds do not go according to the agreement.

3. Lack of socialization and evaluation of the relevant government or extension worker.

4. More irresponsible members.

5. Lack of government oversight.

6. Weak human resources in developing KUB.

7. Minimum escort or supervisor.

8. Lack of verification of fishermen or administration data

Threats (T)

1. Declining fish populations.

2. Lots of loans from banks and loan shark.

3. Weather factors

4. Extortion from government.

5. Sudden emerging fishermen groups/fake groups, with the same members.

6. The distribution of assistance to the relative. 
From the table above, the internal factors can be seen (strengths and weaknesses) as well as external factors (opportunities-threats) in the implementation of Fishermen Community Empowerment Strategy through Rural Fisheries Business Development Program (PUMP) by Marine and Fisheries Office of Padang.

Alternative strategies in the implementation of Fishermen Community Empowerment Strategy through Rural Fisheries Business Development Program (PUMP) by Marine and Fisheries Office of Padang were formulated based on the identification of internal factors (strengths-weaknesses) and external factors (opportunities-threats). Details are below:

Tabel 2. Alternative Fishermen Community Empowerment through PUMP program

\section{S-O Strategy \\ W-O Strategy}

1. Utilizing potential to seize opportunities

2. Revitalizing the existing fishermen's cooperatives through the assistance of competent parties (universities, NGOs, agencies).

3. Cooperating with Koperindag and MSMEs to create other business opportunities (valueadded products).

4. Training the fishermen to prepare for the regeneration of fishermen in continuing the fishing acts.
1. Overcoming weaknesses to seize opportunities

2. Conductingdissemination to KUB and members through a familial approach.

3. Improving supervision so that revolving funds could run smoothly.

4. Conducting intensive assistance to fishermen by involving competent parties (universities, NGOs, etc.)

5. Creating concrete data on fishermen to be fostered or recipients of assistance from the government.

\section{S-T Strategy}

1. Utilizing the potential to face challenges

2. The allocation of business capital by the relevant office to the fishermen as a whole, to reduce dependence on loan sharks or loans from banks.

3. Improving fishing zoning by the authorities (Marine Police, and Marine).

4. Increasing supervision and control ooextorter.

5. Creating clear rules about KUB groups and members and apply them consistently.

6. Involving more independent third parties in distributing aid to fishermen.
1. Minimizing weaknesses to face threats

\section{W-T Strategy}

2. Take action against illegal levies on fishermen.

3. Encourage community participation in order to protect the environment.

4. Minimize the number of group members by creating a limit on the number of group members.

5. Removing group members who can not be accountable for the assistance they receive.

Source: Processed primer data

Based on the table above, it can be seen that the strategy of Fishermen Community Empowerment through Rural Fisheries Business Development Program (PUMP) by Marine and Fisheries Office of Padang was an analytical strategy. 


\section{Conclusions}

It concluded that the strategies found in the implementation of Fishermen Community Empowerment through Rural Fisheries Business Development Program (PUMP) by Marine and Fisheries Office of Padang were 11 strategies: Revitalize existing fishermen's cooperatives (2) Cooperate with Koperindag and UMKM offices (3) Training for fishermen to prepare for regeneration (4) Evenly capital provision, reduce dependence on loan sharks or banks (5) Enforce fishing zoning (6) Improving the supervision on illegal levies (7) Creating clear rules on $\mathrm{KUB} /$ members, and applying them consistently (8) Engaging with more independent third parties in distributing aid 9) Disseminating with KUB/members through familial approaches (10) Improved supervision so that revolving funds could go smoothly (11) Create intensive facilitation schedule for each KUB by involving competent partes (12) Create concrete data about fishermen who will be fostered (13) Take action against extorter (14) Encourage community participation in order to protect the environment (15) Minimize the number of group members by limiting the number of group members (16) Removing irresponsible group members.

\section{References}

Nasution A, Badaruddin. (2005). Isu-Isu Kelautan Dari Kemiskinan Hingga Bajak Laut.Yogyakarta: Pustaka Pelajar

Lexi J Moleong. (2007). Metedologi Penelitian Kualitatif. Bandung: PT. Remaja Rosdakarya.

Rangkuti, Freddy. (2015). Teknik Membedah Kasus Bisnis Analisis SWOT. PT GramediaPustaka Utama. Jakarta.

Sagala, Syaiful. (2011). Manajemen Strategik Dalam Peningkatan Mutu Pendidikan. Alfabeta. Bandung.

Lexi J Moleong. (2007). Metedologi Penelitian Kualitatif. Bandung: PT. Remaja Rosdakarya.

Suharto, Edi. (2010). Pemberdayaan Masyarakat dalam Peningkatan Ekonomi, Bandung: Refika Aditama.

Maritime and Fisheries Office of Padang 2016

Law No 45/2009 on Fisheries.

Law No 32/2014 on Maritime. 